\title{
Driving institutional change: challenge based learning for the University of the 21st Century
}

\author{
Xavier Mas ${ }^{\mathrm{a}}$; Lluís Pastor ${ }^{\mathrm{a}}$; Marta Merino ${ }^{\mathrm{a}}$; Loles González ${ }^{\mathrm{a}}$ and Toni Martínez- \\ Aceituno $^{\mathrm{a}}$ \\ ${ }^{\mathrm{a},}$ Learn Center, Universitat Oberta de Catalunya, Spain.
}

\begin{abstract}
The main challenge faced by higher education is overcoming the gap between university education and the demands of society and the professional world. This gap cannot be accounted for merely in terms of a shortcoming in the relationship between the competencies of academic programmes and the real training needs of lifelong learners, but also involves the mismatch between the design of training models and students' expectations. The UOC has launched the PLA-Niu project in response to this problem. It aims to transform the subjects in the University's programmes into activities designed strictly based on competencies which are aimed at resolving challenges inspired by the professional sphere; to implement a new means of selecting, designing and managing learning resources based on content curation for learning, organising it into specific aggregators for each activity; and to provide a system that enables the production and organisation of training in an agile, flexible and personalisable manner. In this paper, we set out the experience of applying the PLA-Niu in the University as a whole, and present its characteristics, explain the strategies and measures involved in its implementation, and share the reflections of those involved from a critical perspective.
\end{abstract}

Keywords: challenge based education; situated learning; competency based design; new learning models; innovation management; lifelong learning. 


\section{Introduction}

Years after the turn of the twenty-first century, it seems that higher education and the professional world are still living in separate universes. There is a persistent gap between the training offered by academic programmes and the training needs of lifelong learners. According to a study commissioned by the Universitat Oberta de Catalunya (Open University of Catalonia, UOC) on digital learners and the impact of socio-technological and sociocultural trends on education, there is a gap in competencies between graduates from regulated systems and the demands of the labour market and professional environments. This is especially true in terms of technological, creative and business skills (Moyano, Bouchet, Paniagua, \& Mas, 2016). There is also a need for training models that offer shorter and more specific courses which enable training to be better adapted to the competencies required at any given time, instead of investing time and effort in long-term bachelor's and master's degrees with general approaches (Moyano et al., 2016; Guàrdia, Witthaus, Padilla, \& Girona, 2016). Moreover, the various experts consulted for the study all warn of the stress on current education systems and support the idea of creating new more flexible forms of training based on competencies, in order to provide a better response to the needs of learners and the professional world (Mas, 2016). Meanwhile, universities are finding it difficult to evolve in terms of their learning methodologies. In this respect, Bartolomé \& Grané (2013) when discussing universities, say that many of the ideas still predominant in education, such as standardised training and the authority of the teacher, are in contrast with the transformation of significant aspects of the knowledge society, such as copyright, digital identity and information management.

Apart from being an online university, the UOC is an institution that works within this environment. As a general university, it offers official qualifications within the regulated university system to 54,000 students in many different knowledge areas ${ }^{1}$ within the framework of the EHEA, and as such the UOC is affected by the same problems as most similar institutions.

This is therefore the context of which the PLA-Niu project is a part, and it is designed to be a methodological change in the conception of the subjects to be implemented in the entire range of training at the UOC. As we will see below, the characteristics of this new design for training contain the DNA of a whole range of changes which are designed to bring the experience of studying at the UOC closer to the new educational demands of the twentyfirst century.

\footnotetext{
${ }^{1}$ More than 100 master's degrees, 3 doctoral programmes and almost 300 diplomas and specialist courses in various knowledge areas, ranging from computer engineering to business sciences and health sciences. See http://www.uoc.edu/portal/en/universitat/coneix/index.html.
} 


\section{The starting point}

Based on the context described above, the key factors in the initial situation are the major challenges faced by both on-line and classroom-based higher education institutions:

1. The need to train students so that they can cope with the changing nature of the workplace, and develop the competencies that may be associated with it.

2. Provide students with tools to ensure academic success and encourage their continuance in university training programmes.

3. Assist students in their educational planning and time management.

4. Provide teaching staff with the support necessary to keep them constantly updated and involved in the design, monitoring and assessment of the learning process, and promote its innovative and creative character.

5. Highlight and examine in depth the design of training based on the activity and provide contextualised training based on or inspired by real experiences.

6. Ensure a methodological quality standard in subject design.

7. Diversify the range of educational content and resources, to respond to different types of intelligences and relate more closely to the different generations of students that make up today's digital society.

To drive this change and transform this situation, the university has made a methodological commitment involving the implementation of the PLA-Niu project ${ }^{2}$, which covers all the programmes offered by the UOC. This project has been led by the eLearn Center - the centre for research and innovation in digital education at the UOC - with Oberta Publishing, the University's content and educational resources production department, and has been promoted by the Office of the Vice President for Teaching and Learning, as we shall see below.

\section{Description of the methodology implemented}

The PLA-Niu aims to create a methodological change in the subject design of all the programmes offered by the UOC. According to this methodology, each subject is considered in terms of a sequence consisting of what are known as PLA activities (Figure 1). They aim to ensure that competence-based design genuinely impacts on students' training; to contextualise this training activity in challenges and situations related to the professional sphere or to the students' daily lives by applying the principles of situated learning (Guàrdia, Sangrà, \& Ahumada, 2006; Oregon Technology in Education Council, 2007; Stein, 1998; Lave \& Wenger, 1991); and to implement a methodology and a system

\footnotetext{
${ }^{2}$ PLA-Niu is explained in section 3. Description of the methodology implemented.
} 
for managing learning resources based on content curation for learning, which links them closely to the learning process.

Strictly speaking, a PLA activity is a compact form of training activity, which is defined based on a situation related to a challenge, is competence-based and designed around the activity to be carried out by the student. The acronym PLA stands for 'Performance Learning Activity' (Table 1).

Table 1. Definition of Performance Learning Activity.

\begin{tabular}{|c|c|c|}
\hline $\begin{array}{c}\mathbf{P} \\
\text { (PERFORMANCE) }\end{array}$ & $\begin{array}{c}\mathbf{L} \\
\text { (LEARNING) }\end{array}$ & $\frac{\mathbf{A}}{(\text { ACTIVITY) }}$ \\
\hline $\begin{array}{l}\text { The student is guided by a } \\
\text { professional or training } \\
\text { situation in order to obtain a } \\
\text { result related to a challenge. }\end{array}$ & $\begin{array}{l}\text { The aim is to master the skills, } \\
\text { knowledge, attitudes and values } \\
\text { that arise from the competencies in } \\
\text { the programme. }\end{array}$ & $\begin{array}{l}\text { The learning process is } \\
\text { guided by a continuous } \\
\text { assessment activity. }\end{array}$ \\
\hline
\end{tabular}

A PLA activity contains the following items: a challenge, competencies, a continuous assessment activity and the Niu (Figure 1).

As shown below, these items are closely interlinked, with the PLA activity acting as a matrix that ensures the educational consistency of all the components in the learning process:

- Challenge. This contextualises the training activity with a situation related to the professional sphere or with an application in everyday life using an approach focused on overcoming a challenge. This challenge is related to the skills and learning outcomes that lead to the PLA.

- Competencies of the programme that are worked on specifically in the PLA activity, specified in the learning results that are to be obtained. These provide the inspiration for the challenge and guide the design of the activity and its deliverables.

- Continuous Assessment Activity (CAA). This is the learning activity that the student must carry out in order to develop the competencies of the PLA which are contextualised with the challenge. By completing the activity, the student prepares deliverables that act as evidence to assess the PLA. Estimating the minimum time for training that students need is particularly important in the design.

- Niu. The training resources and content required to carry out the CAA successfully. These resources may be produced internally and externally. They are accessible within the PLA by means of a visual aggregator, after a content curation for learning work presents them, highlights their value and contextualises them for use in the training activity. 


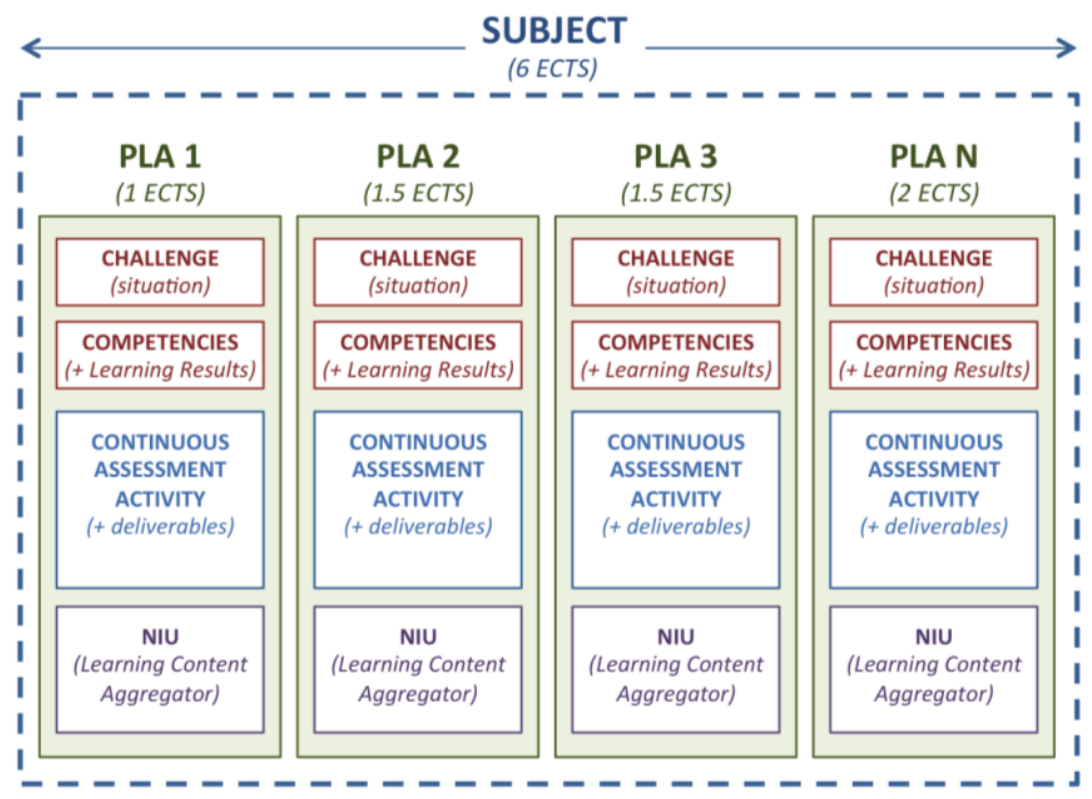

Figure 1. Structure of a subject based on PLA activities (the number of credits may vary).

\section{Experience of implementation}

\subsection{Strategy}

The implementation of the PLA-Niu project is based on four guiding elements, which ensure the quality of the process: (a) a top-down implementation methodology according to the University's strategy; (b) a framework of reference based on studies of trends in higher education; (c) incremental intervention; and (d) personalisation.

(a) At the University, the project is being drived by the Office of the Vice President for Teaching and Learning, and it is led by the eLearn Center and supported by the Library and Technology areas, with information and communication initiatives for all those involved, and cooperation and teamwork encouraged.

(b) Various studies of trends in higher education led by the eLearn Center ${ }^{3}$ are used to provide a framework of reference for the PLA-Niu project.

\footnotetext{
${ }^{3}$ Future Scenarios for Digital Learners (Moyano et al., 2016) and Next Generation Pedagogy: IDEAS for Online and Blended Higher Education (Guàrdia et al. 2016).
} 
(c) We decided on a strategy of incremental intervention, which emphasises the factors that have defined the educational model of the UOC for over 20 years, making them evolve to meet the challenges that will affect education in the coming decades.

(d) The advisory process consists of personalised and intensive support for the teachers' work on creating their subjects.

\subsection{Support for teaching staff in subject design}

Each teacher involved in the PLA-Niu designs their own subjects, accompanied by expert advisers from the eLearn Center during three individual working sessions. The goal at the end of these sessions is to establish the basic structure of each PLA, defining and identifying the main elements: identifying the challenge, a proposal for an activity, measurement of the working time involved in training, and the list of contents and resources that form part of the Niu. The medium containing all this information is a template that we call the Teaching Pre-Project. This document has two basic functions. First, it is where the preliminary design of the subject takes place, and second, it begins the process of requesting, producing and managing the rights to the resources, including their economic management.

\subsection{The PLA-Niu project in figures}

In the long term, the project affects the entire range of training at the UOC. To achieve this objective, its implementation is planned in several phases lasting two months each. Currently, the first phase has been carried out, with the data shown in Table 2. Priority was given to the new subjects and programmes, of which a total of 115 are anticipated for the first semester of the 2017-2018 academic year. In this phase we worked with $45 \%$ of these.

Table 2. Institutional scope of the PLA-Niu project.

\begin{tabular}{|c|c|c|c|c|c|}
\hline & Faculties & Programmes & Subjects & Teaching staff ${ }^{4}$ & Advice sessions \\
\hline $\begin{array}{c}\text { Phase 1 } \\
(\text { Nov.-Dec. } \\
\text { 2016) }\end{array}$ & 5 & 12 & $\begin{array}{c}13 \text { bachelor's } \\
\text { degrees } \\
38 \text { master's } \\
\text { degrees }\end{array}$ & 37 & 150 \\
\hline UOC Total & 7 & $\begin{array}{r}24 \text { bachelc } \\
78 \text { maste } \\
249 \text { postgrad } \\
\text { specialisation }\end{array}$ & $\begin{array}{l}\text { r's degrees } \\
\text { 's degrees } \\
\text { late diplomas, } \\
\text { s and courses }\end{array}$ & 262 & \\
\hline
\end{tabular}

\footnotetext{
${ }^{4}$ The UOC has 262 faculty members responsible for subject design and 2,991 teachers involved in classroom teaching.
} 


\section{Conclusions}

After the first phase had been completed, the project was evaluated, which enabled us to identify areas for improvement and items to be reinforced, and these measures will be implemented in later stages. The experience also enabled adjustments to be made during the process. The evaluations and reflections made led to the following conclusions:

- Personalised advice has an effect on teacher training because it enables teachers to cope autonomously with the design of future subjects. This is expected to have a positive impact on the empowerment of teachers in terms of the PLA-Niu.

- The project requires increased collaboration between the various parties involved, and creates new working synergies that incrementally foster opportunities for change in the institution as a whole.

- In order to roll out the change to the institution as a whole, the support and advice teams must be expanded and the management processes and tools they use must be optimised.

- The PLA-Niu leads to changes in the processes of creation and management of subjects, from their design to their implementation in the classroom. This changes how teachers' work is organised, which led to some resistance.

- Managing change is a difficult process which involves adapting to new ways of working, thinking about subjects and like all changes, creates resistance; however, a process with clear planning, with a permanent support team that actively listens to specific needs, and confidence in the project, shows that it is possible to implement it within the stipulated deadlines.

- The process leads to the achievement of a common standard of quality in all subjects. At the same time, it has mechanisms to ensure the PLA-Niu adapts to the specific characteristics of each subject and the application of new training methodologies.

- Fragmentation into PLA activities lays the foundations for the future implementation of a range of training that is more flexible and dynamically adaptable to the demands of learners, to the pace of development of society and to the professional world.

- The PLA-Niu project suggests a need to create new training scenarios and environments, as well as to redefine the roles of teachers, incorporating new figures into the institution. An example of this would be content curation for learning.

From this point, and based on our experience, in addition to continuing with the next phases of work, there is a clear need to observe and analyse the result of the implementation of the PLA-Niu subjects in the classroom, in terms of both their workings from the point of view of teaching and their acceptance by students. 


\section{References}

Bartolomé, A., \& Grané, M. (2013). Interrogantes educativos desde la sociedad del conocimiento. Aloma. Revista de Psicologia, Ciències de l'Educació i de l'Esport, 31(1), 73-81.

Guàrdia, L., Sangrà, A., \& Ahumada, M. (2006). L'elaboració dels nous plans docents en l'EEES; una proposta sistèmica. In Jornades en xarxa sobre l'Espai Europeu d'Educació Superior. Barcelona: Universitat Oberta de Catalunya. Retrieved from http://vgweb.epsevg.upc.es/fdv/docs/sangra_et_al_2006.pdf

Guàrdia, L., Witthaus, G., Padilla, B., \& Girona, C. (2016). Next Generation Pedagogy: IDEAS for Online and Blended Higher Education. Final report of the FUTURA (Future of University Teaching: Update and a Roadmap for Advancement) project. (L. Guàrdia, Ed.). Barcelona. Retrieved from http://hdl.handle.net/10609/51441

Lave, J., \& Wenger, E. (1991). Situated Learning: Legitimate Peripheral Participation. Cambridge: Cambridge University Press.

Mas, X. (2016). Future Scenarios for Digital Learners: Sociotechnological and sociocultural trends will transform the current educational ecosystem. In G. Ubachs \& L. Konings (Eds.), Enhancing European Higher Education "Opportunities and impact of new modes of teaching" Overview of papers on enhancement of European Higher Education as presented during the Online, Open and Flexible Higher Educaiton Conference in Rome (pp. 45-60). Rome: EADTU. Retrieved from http://conference.eadtu.eu/images/Proceedings/Conference_proceedings_2016_defcomp ressed2.pdf

Moyano, V., Bouchet, C., Paniagua, S., \& Mas, X. (2016). Escenarios de futuro para los digital learners. Tendencias sobre la experiencia digital de los usuarios de la red y su impacto en la educación superior en línea. (V. Moyano, C. Bouchet, \& X. Mas, Eds.). Barcelona. Retrieved from http://hdl.handle.net/10609/48721

Oregon Technology in Education Council (OTEC). (2007). Learning Theories and Transfer of Learning.

Stein, D. (1998). Situated Learning in Adult Education. ERIC Digest, (195). Retrieved from http://files.eric.ed.gov/fulltext/ED418250.pdf 